Chirurgia (2019) 114: 376-383

No. 3, May - June

Copyright@ Celsius

http://dx.doi.org/10.21614/chirurgia.114.3.376

\title{
The Potential Prognostic Significance of the Laboratory Risk Indicator for the Necrotizing Fasciitis (LRINEC) Score in Necrotizing Fasciitis
}

\author{
Doğan Gönüllü', Ahmet Serkan Ilgun', Okan Demiray', Samed Sayar', Ahmet Muzaffer Er', Gulay Kır², \\ Ferda Nihat Koksoy ${ }^{1}$
}

${ }^{1}$ Health Sciences University, Gaziosman Pașa Taksim Training And Research Hospital, General Surgery, Istanbul, Turkey ${ }^{2}$ Koç University, Medicine Faculty, Anesthesiology And Reanimation Department, Istanbul, Turkey

Corresponding author:

Associate Professor Dogan Gonullu University of Health Sciences, Gaziosmanpașa Taksim Training and Research Hospital, General Surgery, Istanbul, Turkey

E-mail: dogangonullu@yahoo.com

\section{Rezumat}

Semnificația potențială a prognosticului indicatorului de risc de laborator pentru fasceita necrozantă (LRINEC) în cazurile de fasceită necrozantă

Context: Discutăm despre rolul indicatorului de risc de laborator pentru fasceita necrozantă (LRINEC) asupra prognosticului acestei boli. Fasceita necrozantă $(\mathrm{NF})$ se caracterizează prin răspândirea rapidă a infecției şi a necrozei țesutului moale şi a fasciei.

Metode: Treizeci de pacienți (17 bărbați, 13 femei, vârsta medie 57,5 ani) au fost tratați în perioada 2011-2016; au fost analizați retrospectiv în ceea ce priveşte vârsta, sexul, agenții microbiologici izolați, modalitățile de tratament şi rata mortalității.

Rezultate: Majoritatea infecțiilor au fost detectate în perineu (14, $46,7 \%)$, alte localizări ale infectiei fiind regiunea presacrală $(3,10 \%)$, regiunea abdominală după intervenție chirurgicală de elecție $(10,33,3 \%)$ şi intervenție chirurgicală de urgență (2, 6.7\%). 53,3\% dintre pacienți au prezentat cel puțin un factor comorbid predispozant, cum ar fi diabetul zaharat, hipertensiunea, cardiomiopatia şi insuficiența cardiacă congestivă. Culturile de țesut au fost pozitive la $12(40 \%)$ pacienți. Scorul mediu LRINEC la internare a fost de $8,5 \pm 2,85$. A existat o corelație puternică între scorul LRINEC şi vârsta pacientului $(p=0,018, R=0,43)$. Scorul LRINEC nu a fost afectat nici de sex, nici de prezența oricăror comorbidități. Pacienții au fost clasificați conform sistemului de stadializare Wang şi Wong: 1 pacient în stadiul 1 (3,3\%), 15 în stadiul $2(50 \%)$ şi 14 în stadiul 3 (46,7\%); pacientii cu stadii Wang şi Wong mai mari aveau scoruri LRINEC semnificativ mai ridicate. Rata mortalității este de 16,7\%. 
Scorul mediu LRINEC al pacienților decedați a fost de 9,2 $\pm 2,2$ şi al pacienții în viață de 8,36 $\pm 2,9$. Concluzii: Chiar dacă scorul LRINEC şi stadiul Wang şi Wong au fost semnificativ legate de internarea la terapie intensivă, efectul lor direct asupra mortalității nu a fost semnificativ în studiul nostru.

Cuvinte cheie: fasceită necrozantă, indicator de risc de laborator pentru fasceita necrozantă, stadiile Wang şi Wong, tratamentul fasceitei necrozante.

\section{Abstract}

Background: We discuss the role of Laboratory Risk Indicator for the Necrotizing Fasciitis (LRINEC) on the prognosis of this disease. Necrotizing Fasciitis (NF) is characterised by rapid spreading of infection and necrosis of the soft tissues and fascia.

Methods: Thirty patients (17 male, 13 female, mean age 57.5 years) were treated between 20112016 (in our center); they were analysed retrospectively regarding age, sex, isolated microbiological agents, modalities of treatment and mortality rate.

Results: The majority of the infections were detected in the perineum (14 patients). Other sites of infection were: the presacral region (3 patients), as well as abdominal region after elective (10 patients) and emergency surgery (2 patients), respectively. $53.3 \%$ of patients had at least one predisposing comorbid factor such as diabetes mellitus, hypertension, cardiomyopathy and congestive heart failure. The tissue cultures were positive in 12 patients. Mean LRINEC score on admission was $8.5 \pm 2.85$. There was a strong correlation between LRINEC score and patient age $(\mathrm{p}=0.018, \mathrm{R}=0.43)$. LRINEC score was affected by neither gender nor the presence of any $\mathrm{co}^{-}$ morbidities. The patients were classified according to Wang and Wong staging system, as follows: one patient in stage 1, 15 patients in stage 2 and 14 patients in stage 3. Patients with higher Wang and Wong stages had significantly higher LRINEC scores. The mortality rate was $16.7 \%$. The mean LRINEC score of deceased patients compared to patients who were successfully treated was $9.2 \pm 2.2$ and 8.36 \pm 2.9 .

Conclusion: Even though LRINEC score and Wang and Wong stage were significatly related with ICU stay, their direct effect on mortality wasn't significant in our study.

Key words: necrotizing fasciitis, laboratory risk indicator for necrotizing fasciitis, Wang and Wong stages, treatment of necrotizing fasciitis

\section{Introduction}

Necrotizing Fasciitis (NF) is a life threating, polymicrobial necrotizing infection of subcutaneous soft tissues and fascial planes. Claude Colles (France) defined the necrotizing fasciitis in 1783, then Joseph Jones (USA) who reported the cases of gas gangrene treated in the American Civil War, made the first description of NF. In 1883 JA Fournier described this entity as a localised perineal soft tissue infection. Since its first description, the mortality rate has not changed and remains to be reported between $25-35 \%(1,2)$. Difficulty of recognition and delay in the aggresive surgical debridment are the main causes for the high mortality rates (3). Diabetes mellitus (DM), malnutrition and immunosupression are well-known predisposing factors for developing NF (3).

Early diagnosis, appropriate antimicrobial therapy and aggresive debridment are key factors of succesful NF treatment (4). As distinguishing $\mathrm{NF}$ from other soft tissue infections in the early phase of its course, precise diagnosis and staging is important to 
achieve good treatment results. Wang and Wong staging, first described in 2005 by Yi-Shi Wang and Chin-Ho Wong is a chronological categorization of the skin manifestations as the disease progresses through early to late stages (5). The Laboratory Risk Indicator for Necrotizing Fasciitis (LRINEC) is a sixparameter scoring system designed to differentiate NF from other soft tissue infections. LRINEC scores $>6$ have a specifity higher than $90 \%$ and sensitivity higher than $95 \%$ for the diagnosis of NF (6). Beside being an usefull diagnostic tool, the LRINEC score was also found to have some prognostic value in some studies. The aim of our study is to evaluate LRINEC score and Wang and Wong classification as a prognostic tool for the patients treated with NF.

\section{Methods}

After institutional review board approval, retrospective analyses were performed on medical reports of all patients treated with the diagnosis of NF in the University of Health Sciences, Gaziosmanpaşa Taksim Taining and Research Hospital, Turkey between 2011 and 2016. Thirthy three consecutive patients with the diagnosis of NF were identified from the hospital medical record data base. Diagnosis of necrotizing fasciitis was provided according to the operative findings such as greyish colour of the debrided necrotizing fascia, easy dettachment of normally adherent fascial planes, lack of bleeding on the cut surface of the involved fascia and the presence of dish water pus odor. Histopathologic tissue confirmation of the diagnosis was performed if available.

Of the initial 33 patients, 30 patients who
Table 1. LRINEC Scoring system (a score $\leq 5$ points indicate a low risk for NF; 6-7 points indicate an intermediate risk of NF; $\geq 8$ points indicate a high risk of NF)

\begin{tabular}{lc}
\hline Variables & Score \\
\hline C-reactive Protein(mg/L) & \\
$\quad<150$ & 0 \\
$\geq 150$ & 4 \\
$\quad$ Total white blood cell count $\left(\right.$ per $\left.\mathrm{mm}^{3}\right)$ & \\
$\quad<15$ & 0 \\
$15-25$ & 1 \\
$>25$ & 2 \\
\hline Hemoglobin (gr/dL) & \\
$>13.5$ & 0 \\
$11-13.5$ & 1 \\
$\quad<11$ & 2 \\
Sodium (mmol/L) & \\
$\geq 135$ & 0 \\
$\quad<135$ & 2 \\
\hline Creatinin(mg/dL) & \\
$\leq 1.6$ & 0 \\
$>1.6$ & 2 \\
\hline Glucose (mg/dL) & \\
$\leq 180$ & \\
$>180$ & 0 \\
\hline
\end{tabular}

had fully available medical reports for LRINEC score and Wang and Wong Classification in the first admission day were included i7 the study. LRINEC Score was calculated by considering six biological variables: C-reactive protein (CRP), white blood cell count, hemoglobin, creatine, glucose and sodium levels $(4,5)$ (Table 1). The Wang and Wong staging was applied according to the orginal description (Table 2).

\section{Statistical Analysis}

The statistical analysis was performed using the SPPS software version 20 . The variables were assessed by means and standard

Table 2. Wang and Wong stage description

\begin{tabular}{llll}
\hline & Stage 1 (early) & Stage 2 (intermediate) & Stage 3 (late) \\
\hline Clinical features & Tendernes to palpation & Blister or bullae formation & Crepitus \\
& (extending beyond the apparent & serous fluid) & Skin anesthesia \\
& area of skin involvement) & & Skin necrozis with dusky \\
& Erythema & & discoloration \\
& Swelling & \\
Calor (warm skin) & & \\
\hline
\end{tabular}


deviation, after checked for normality in a preliminary analysis (visual and analytical methods were used). For the variables with no normal distribution, median and range was reported. The variables were assessed by frequency. For normally distributed variables, independent-samples $t$ test and Pearson corelation coefficient were used for statistical analysis. The Mann-Whitney U test was used when the groups were small and / or the data was non-normally distributed or qualitative. Logistic regression was used to determine independent predictive factors of patient outcome. Hosmer-Lemeshow goodness of fit statistics were used to assess model fit. For an easier interpretaton of the multivariate analysis, the Relative Risk (RR) with $95 \%$ confidence interval were presented. A p-value of less than 0.05 was considered to show statistically significant result.

\section{Results}

Seventeen of 30 patients, were male and 13 were female. The median age was 57.5 (20-81) years. The majority of the infections were detected in the perineum, as a consequence of perianal abscess (14 patients). Other sites of infection were: the presacral region due to pilonidal cyst abscess (3 patients), abdominal region after elective and emergency surgery (10 and 2 patients respectively) (Fig. 1). More than half of the patients (16) had at least one predisposing comorbid factor such as diabetes mellitus, hypertension, cardiomyopathy and congestive heart failure. The most frequent $(50 \%)$ comorbid factor was diabetes mellitus.

The tissue cultures were positive in 12 patients, half of whom were type 1 (polymicrobial) and the other half were type 3 (monomicrobial gram negative bacteria). The most common isolated microbiological agents were E Colli, Acinetobacter spp and Pseudomonas aeroginosa.

Mean LRINEC score on admission was $8.5 \pm 2.85$. Five patients had LRINEC scores $<$ 6 and 25 patients had scores of 6 or more. There was a strong correlation between LRINEC score and patient age $(p=0.018$, $\mathrm{R}=0.43$ ). LRINEC score was affected by neither gender nor the presence of any comorbidities ( $p=0.24$ and $p=0.10$ respectively). Although patients with higher LRINEC scores had longer hospital stay, the relation between LRINEC score and hospital stay was not significant (Table 3).

When the patients were classified according to the Wang and Wong staging system, there was one patient in stage 1,15 in stage 2 and 14 in stage 3 , respectively. When stage 1 and 2

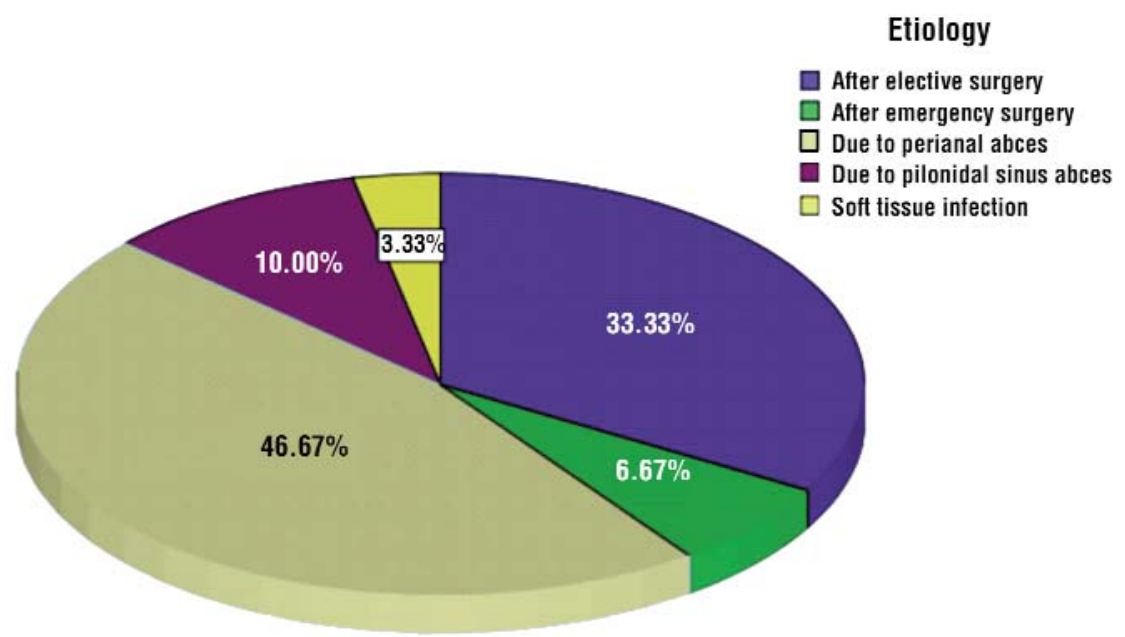

Figure 1. Etiology of necrotizing fasciitis 
Table 3. Relations between the possible factors that may affect the outcome of NF, LRINEC scores and Wang and Wong classification.

\begin{tabular}{|c|c|c|c|c|c|c|}
\hline \multirow[t]{2}{*}{ Factors } & \multicolumn{3}{|c|}{ LRINEC } & \multicolumn{3}{|c|}{ Wang \& Wong stage } \\
\hline & $\begin{array}{c}\text { Score }<6 \\
(N=5)\end{array}$ & $\begin{array}{c}\text { Score } \geq 6 \\
(N=25)\end{array}$ & $\mathrm{p}$-value & Stage $1+2$ & Stage 3 & p-value \\
\hline Age (years) & $29(20-50)$ & $60(25-81)$ & $0.001^{*}$ & $50.1 \pm 18$ & $60.6 \pm 8.3$ & 0.07 \\
\hline \multicolumn{7}{|l|}{ Gender } \\
\hline Male & 4 & 13 & $0.240 * *$ & 10 & 7 & 0.49 \\
\hline Female & 1 & 12 & & 6 & 7 & \\
\hline \multicolumn{7}{|l|}{ Comorbidities } \\
\hline Yes & 1 & 15 & $0.10^{* *}$ & 8 & 8 & 0.69 \\
\hline No & 4 & 10 & & 8 & 6 & \\
\hline Hospital stay (days) & $14(9-24)$ & $21(4-92)$ & $0.210^{*}$ & $20.7 \pm 12.2$ & $25.7 \pm 22$ & 0.59 \\
\hline
\end{tabular}

patients were classified together as "low stage" group and stage 3 patients as "high stage" group, no statistically significant differences between these two groups was noted in regards to age, gender and the presence of any comorbidities. Patients classified as stage 3 had longer hospital stay but the difference did not reach statistical significance, either (Table 3).

Patients with higher Wang and Wong stages had significantly higher LRINEC scores (Table 3, 4). Twelve (40\%) patients needed Intensive Care Unit (ICU) stay during the course of their treatment. Patients requiring ICU stay had higher LRINEC scores at admission (Table 4), as well as significantly higher Wang and Wong stage (Table 5).

The mortality rate is $16.7 \%$. The mean LRINEC score of deceased patients was $9.2 \pm 2.2$ and $8.36 \pm 2.9$ in patients who survived. Wang and Wong stage, LRINEC score and other possible factors that may be related with mortality such as age, gender and presence of any comorbidity were investigated. In univariate analyses, only older age was significantly related with mortality. In the multivariate analysis, age was once again detected as the only factor related to in patient mortality $\left(\mathrm{RR}=1.17,95 \% \mathrm{CI}: 1.01^{-}\right.$ 1.36, $\mathrm{p}=0.03$ ) (Table 6). Even though the LRINEC score and Wang and Wong stage

Table 4. Relations between LRINEC scores and Wang and Wong stages, LRINEC scores and ICU stay

\begin{tabular}{|c|c|c|c|c|}
\hline & & Number of Patients & Mean LRINEC Score & $\mathbf{p}$ \\
\hline Wang and Wong Stage & $\begin{array}{c}\text { Low(Stage1+2) } \\
\text { High(Stage 3) }\end{array}$ & $\begin{array}{l}16 \\
14\end{array}$ & $\begin{array}{c}7.5 \pm 3.09 \\
9.64 \pm 2.09\end{array}$ & $0.037^{\star}$ \\
\hline ICU Stay & $\begin{array}{l}\text { Yes } \\
\text { No }\end{array}$ & $\begin{array}{l}12 \\
18\end{array}$ & $\begin{array}{c}10.08 \pm 1.97 \\
7.44 \pm 2.89\end{array}$ & $0.01 *$ \\
\hline
\end{tabular}

*Independent sample $t$ test

Table 5. ICU stay and Wang and Wong stages

\begin{tabular}{lccc}
\hline & Low Wang and Wong Stage & High Wang and Wong Stage & p value \\
\hline ICU stay & $2(12.5 \%)$ & & $0.001^{*}$ \\
Yes & $14(87.5 \%)$ & $10(71.4 \%)$ & \\
No & & $4(\% 28.6)$ & \\
${ }^{*}$ Chi square & & &
\end{tabular}


Table 6. Univariate and Multivariate Analyses of In Hospital Mortality

\begin{tabular}{lccccccccc}
\hline & \multicolumn{3}{c}{ Univariate Analyses } & \multicolumn{3}{c}{ Multivariate Analyses* } \\
\hline Risk Factor for Mortality & RR & 95\% Cl for RR & P value & RR & 95\% Cl for RR & P value \\
\hline & \multicolumn{3}{c}{ Lower } & Upper & & & Lower & Upper \\
\hline Gender(female vs male) & 0.44 & 0.06 & 3.15 & 0.41 & 0.40 & 0.03 & 5.36 & 0.49 \\
Presence of a comorbid factor (No vs Yes) & 1.38 & 0.19 & 9.76 & 0.74 & 0.46 & 0.28 & 7.51 & 0.58 \\
LRINEC Score & 1.12 & 0.77 & 1.62 & 0.54 & 0.95 & 0.47 & 1.91 & 0.90 \\
\hline Wang and Wong Stage (high vs low) & 1.90 & 0.27 & 13.4 & 0.51 & 0.66 & 0.35 & 12.7 & 0.78 \\
\hline ICU Stay (no vs yes) & 2.66 & 0.37 & 19.06 & 0.32 & 2.08 & 0.18 & 23.19 & 0.55 \\
\hline Age & 1.17 & 1.01 & 1.36 & 0.03 & 1.17 & 1.01 & 1.36 & 0.03 \\
\hline
\end{tabular}

*Logistic regression Backward LR

were significatly related with ICU stay, their direct effect on mortality wasn't significant in our study.

\section{Discussion}

In 1883, JA Fournier, a specialist in dermatovenerology, described localised necrotizing infection of the perineum in five male patients. Athough large series report necrotizing fasciitis as being more common in males $(3,7)$, a few studies reported that females were more commonly affected $(8,9)$. In our study, despite the fact that males were predominantly affected, male/female ratio was relatively close (1:3). Our balanced gender distribution can be attributed to NF localisation in our patients. $\mathrm{NF}$ was located in anatomival regions other than the perineal area in more than half of our patients.

Patients with NF are usually in their fifties $(2,7)$. In our study, median age was 57.5 years (20-81), which is consistent with previous studies. In some studies advanced age was considered as an independent predictor of mortality $(10,11)$. McHenry at al showed that older patients had significantly higher mortality rates in their series (19). El-Menyar et al confirmed that finding in their larger series with 294 patients (12). Our findings were consistent with previous studies. In our study, all deceased patients were aged 60 years or older. In univarite analyses, older patients had significantly more mortality rates. In multivariate analyses, older age was determined as the only factor effecting mortality in our study.
$\mathrm{NF}$ can develop in any region of the body. Perineum is one of the most common sites for NF (12). In our study, consistent with literature, perineum was the most common localisation of $\mathrm{NF}$; in cases of urogenital localisation there was no testicular involvement in our cases.

The dominant co-morbid diseases in $\mathrm{NF}$ are diabetes mellitus, obesity and hypertension $(2,13)$. Diabetes mellitus was the most common co-morbid disease in our study.

The LRINEC score was first described in 2005 to distinguish NF from other soft tissue infections. A score 6 or more has $92 \%$ positive predictive value and $96 \%$ negative predictive value for the diagnosis of NF. It is useful to stratify patients as low (score 5 or less, probability of $\mathrm{NF}<50 \%$ ), medium (6-7, probability of NF c. $50-75 \%$ ) and high risk (8 or more, probability of $\mathrm{NF}>75 \%$ ) risk of $\mathrm{NF}$, in order to achieve a timely diagnosis and plan appropriate theraphy (5). In a study by Colak at al (9) which investigated 25 patients with NF, mean LRINEC score was 4.6 \pm 2.7 . Another large cohort by El-Menyar at al (12) with $294 \mathrm{NF}$ patients, mean LRINEC score was $6.28 \pm 2.9$ and $45 \%$ of patients had LRINEC score $<6$. In our study only 5 patients $(16 \%)$ were in low LRINEC group (Table 3) and our mean LRINEC score value was 8.5 \pm 2.8 . Our high mean LRINEC score rates could be related to delay in diagnosis or delay in referral to the hospital.

Wang and Wong staging reflects chronological skin changes during the course of NF. Since underlying fascia is the source of infection in 
NF, skin manifestations are secondary changes due to progressive ischemia. In stage 1 disease, skin manifestatios like swelling and calor are indistinguishable from other soft tissue infections. In stage 2, due to progressive infection of deep fascia, perferator vessels supplying the skin become progressively thrombosed, which leads to consecutive blisters and bulla formation. In stage 3, progressive ischemia results in hemorrhagic bullae, skin anesthesia, and skin gangrene (5). In our study, there was a strong correlation between Wang and Wong stage and LRINEC score $(\mathrm{p}=0.037)$. Patients with high Wang and Wong stages tend to have high LRINEC scores (Table 4). To the best of our knowledge, this is the first description of the aforemebtioned correlation in the English Literature.

The mortality of NF is reported as approximately $25 \%$ (12). Although DM is a well known predisposing factor for NF, its effect on mortality is less clear. Yilmazlar at al could not detect $\mathrm{DM}$ as a prognostic factor in their study (15). In their 60 patients-series, Kalaivani at al did not show a correlation between mortality and DM (16). In our study, as with previous ones, neither DM nor other co-morbid factor was associated with mortality.

Gender could be another factor related to mortality. A study authored by Misiakos at al, showed that female gender was found to have significant association with mortality (17). In contrast with that study, Yanar didn't detect a relationship between gender and mortality in their series (18). Our study also did not detect a significant association between gender and mortality.

Besides its diagnostic use, LRINEC score was also determined as a predictor of mortality in some studies $(9,19,20)$. In their study of 209 patients, $\mathrm{Su}$ at al reported that mortality in patients with LRINEC score $\geq 6$ was significantly higher. They did not, however, detect a significant difference in hospital stay between patients with LRINEC score $\geq 6$ or $<6$, respectively. In contrast, El-Manyar at al showed a significant difference in mortality between patients with LRINEC scores below or above 6 . Also, there was a significant difference in hospital stay between two groups in their study. On the other hand, Corona at al could not determine a significant difference in mortality between patients with LRINEC scores below and above 6 , although non-surviving patients tended to have high scores (21). In our study, although non-surviving patients had higher LRINEC scores, there was no statistically significant difference in terms of mortality in patients depending on LRINEC score. Although patients with high LRINEC scores tend to have longer hospital stay, the relationship wasnt significant. ICU admission was significantly higher in patients with high LRINEC scores.

Wang and Wong staging is a clinical staging system of necrotizing fasciitis based on the evolving cutaneous features. Stage migration from early to late stage necrotizing fasciitis is evident in the majority of patients. In our study, we investigated the relationship between Wang-Wong stages and mortality. Stage 3 patients tended to have longer hospital stays. Even though there was not a significant relationship between mortality and WangWong stages, we reported significantly higher rates of ICU admissions in patients stage 3 or higher. Also Wang-Wong stage 3 patients has significantly higher LRINEC scores.

Retrospective design and limited patient number were limitations of our study.

\section{Conclusion}

Results of our study LRINEC score and Wang \& Wong staging are useful to detect necrotizing fasciitis severity. While all patients with higher LRINEC scores and who were classified as "high risk" in Wang \& Wong classification had longer hospital stay, we could not notice a significant relationship with mortality rate.

\section{Conflict of Interest}

The authors declare no conflicts of interests.

\section{References}

1. Jean- Alfred Fournier 1832-1914. Gangrene foudroyante la verge (overwhelming gangrene). Dis Colon Rectum 1988,31(12):984988. 
2. Sorensen MD. Fournier's Gangrene: Epidemiology and Outcomes in the General US Population. Urol Int. 2016;97(3):249-259.

3. Misiakos EP, Bagios G, Patapis P, Sotiropoulos D, Konavidis P, Machairas A. Current concepts in the management of necrotising fasciitis. Frontiers in Surgery.2014:1:1-10.

4. Norton KS, Johnson LW, Perry T, Perry KH, Sehon JK, Zibari GB. Management of Fournier's gangrene: an eleven year retrospective analysis of early recognition, diagnosis, and treatment. Am Surg. 2002;68(8):709-713.

5. Wang $\mathrm{YS}$, Wong $\mathrm{CH}$. International Journal of Dermatology. 2007:46; 1036-1041.

6. Wong $\mathrm{CH}$, Khin LW, Heng KS, Tan KC, Low CO. The LRINEC (Laboratory Risk Indicator for Necrotizing Fasciitis) score: a tool for distinguishing necrotizing fasciitis from other soft tissue infections. Crit Care Med. 2004:32(7):1535-1541.

7. Eke N. Fournier's gangrene: a review of 1726cases. Br J Surg 2000; 87: 718-728

8. Tilkorn DJ, Citak M, Fehmer T, Ring A, Hauser J, Al Benna S, et al. Characteristics and differences in necrotizing fasciitis andgas forming myonecrosis: a series of 36 patients. Scand J Surg. 2012;101:51-55.

9. Colak E, Ozlem N, Kucuk GO, Aktimur R, Kesmer S. Laboratory Risk Indicators for Necrotizing Fasciitis and Associations with Mortality. Turk J Emerg Med. 2016:26;14(1):15-19.

10. Sorensen MD, Krieger JN, Rivara FP, Klein MB, Wessels H. Fournier's gangrene: management and mortality predictors in a population based study. J Urol , 2009:182;2742-2747,

11. Rea Wj, Wyryck WJ.Necrotising fasciitis. Ann Surg, 1970:172;957.

12. Ayman El-Menyar, Mohammad A. The laboratory risk indicator for necrotizing fasciitis (LRINEC) scoring: the diagnostic and potential prognostic role.Scand J Trauma Resusc Emerg Med. 2017; 25: 28.

13. Das DK, Baker MG, Venugopal K.Risk factors, microbiological findings and outcomes of necrotizing fasciitis in New Zealand: a retrospective chart review. BMC Infect Dis. 2012:12;348.

14. Taro Shimizu, Yasuhara Tokuda. Necrotizing Fasciitis. Inter Med. 2010:49:1051-1057.

15. YIlmazlar T, Alpaslan EO, Ozguc HA. Necrotising soft tissue infections: APACHE IIScore, Dissemination, and Survival. World J of Surgery, 2007;31:9:1858-1862.

16. Kailavani V, Hiremath BV, Indumathi VA. Necrotising soft tissue infection-risk factors for mortality. J Clin Diagn Res. 2013;7:16621665.

17. Misiakos EP, Bagias G, Papadopoulos I, Danias N, Patapis P, Machairas $N$ et al.Early diagnosis and surgical treatment for necrotising fasciitis:a multicenter study. Front Surg. 2017; 4:5.

18. Yanar H, Taviloğlu K, Ertekin C. Fournier's gangrene: risk factors and strategies Formanagement. World J Surg. 2006:30(9):17501754.

19. Su YC, Chen HW, Hong YC, Chen CT, Hsiao CT, Chen IC.Laboratory risk indicator fornecrotizing fasciitis score and theoutcomes. ANZ J Surg. 2008; 78: 968-972.

20. El-Menyar A, Asim M, Mudali IN, Mekkodathil A, Latifi R, Al-Thani $\mathrm{H}$. The laboratory risk indicator for necrotizingfasciitis (LRINEC) scoring: the diagnosticand potentialprognosticrole. Scand $\mathrm{J}$ Trauma, ResuscEmerg Med 2017, 25:28.

21. Corona PS, Erimeiku F, Reverté-Vinaixa MM, Soldado F, Amat C, Carrera L. Necrotising fasciitis of the extremities: implementation of new management Technologies. Injury, 2016, suppl 3:66-71. 